\title{
Proximate Composition, Physicochemical Properties and Antioxidant Activity of Flaxseed
}

\author{
Omer Adam Omer Ishag ${ }^{1^{*}}$, Ayat A. Khalid ${ }^{1}$, Amina Abdi ${ }^{1}$, \\ Ibrahim Yaagoub Erwa ${ }^{1}$, Awadalla Babiker Omer ${ }^{1}$ and Azhari H. Nour ${ }^{1}$ \\ ${ }^{1}$ Department of Applied and Industrial Chemistry, Faculty of Pure and Applied Science, International \\ University of Africa, Sudan.
}

\begin{abstract}
Authors' contributions
This work was carried out in collaboration among all authors. Author OAOI designed and administered the study. Authors AAK and AA performed experimental work, analyzed the data and wrote the first draft of the manuscript. Author IYE performed the statistical analysis and revised the manuscript. Authors $A B O$ and $A H N$ helped supervise the study and revised the manuscript. All authors read and approved the final manuscript.

Article Information DOI: $10.9734 / A R R B / 2019 / v 34$ i230148 Editor(s):

(1) Dr. Viduranga Y. Waisundara, Australian College of Business and Technology, Sri Lanka. Reviewers: (1) Aurelia Magdalena Pisoschi University of Agronomic Sciences and Veterinary Medicine of Bucharest, Romania. (2) Iwona Rybakowska, Medical University of Gdansk, Poland. Complete Peer review History: http://www.sdiarticle4.com/review-history/53964
\end{abstract}

Original Research Article

Received 10 November 2019

Accepted 13 January 2020

Published 21 January 2020

\section{ABSTRACT}

Aims: The aims of this study were to investigate the proximate composition of flaxseed; physiochemical properties and antioxidant activity of flaxseed.

Study Design: Using standard analytical methods to determine the proximate composition of flaxseed, extraction of flaxseed in different trials under the same conditions using two different solvents and investigating their physicochemical properties and antioxidant activity.

Place and Duration of Study: This study was conducted in the laboratory of department of applied and industrial chemistry, International University of Africa, University of Medical Sciences and Technology and National Centre for Research, Khartoum - Sudan, during June 2019.

Methodology: The prepared sample of flaxseeds was tested for proximate composition and then extracted with petroleum ether and n-hexane. The extracted oil was then subjected to physicochemical analysis, GC-MS analysis and antioxidant activity test.

Results: The oil yield of flaxseed was high $21.95 \%$ and $28.29 \%$ with n-hexane and petroleum ether respectively. The results obtained for proximate composition were: moisture (8.50 $\pm 0.49 \%)$, ash $(1.96 \pm 0.00 \%)$, fiber $(20.23 \pm 3.47 \%)$, protein $(21.00 \pm 0.74 \%)$, fat $(43.17 \pm 0.99 \%)$ and

*Corresponding author: E-mail: adamomer4@gmail.com; 
carbohydrate $(5.14 \pm 2.73 \%)$. The physicochemical properties of $n$-hexane and petroleum ether extracted flaxseed oils were: density $\left(0.92 \pm 0.00 \mathrm{~g} / \mathrm{cm}^{3}\right)$, refractive index $(1.47 \pm 0.00$ and $1.48 \pm$ 0.01 at $\left.28^{\circ} \mathrm{C}\right)$, acid value $(0.76 \pm 0.10$ and $0.75 \pm 0.20 \mathrm{mg} \mathrm{KOH} / \mathrm{g})$, peroxide value $(4.67 \pm 1.00$ and $\left.2.69 \pm 0.55 \mathrm{meq}_{2} / \mathrm{kg}\right)$, saponification value $(185.61 \pm 0.56$ and $187.83 \pm 2.08 \mathrm{mg} \mathrm{KOH} / \mathrm{g} \mathrm{oil})$, unsaponifiable matter $(5.57 \pm 0.64$ and $2.83 \pm 0.23 \mathrm{mg} \mathrm{KOH} / \mathrm{g}$ oil) and iodine value $(97.24 \pm 0.86$ and $97.44 \pm 2.93 \mathrm{~g} / 100 \mathrm{~g}$ ) respectively. Statistical analysis showed no significant difference between the means of the two data sets of physicochemical properties of flaxseed oils extracted with the two solvents used at $95 \%$ confidence level. The GC-MS spectrum of flaxseed oil extracted with n-Hexane revealed presence of 27 fatty acids, the predominant were linoleic acid $(46.53 \%)$, palmitic acid (18.04\%), stearic acid (12.23\%), linolenic acid $(11.63 \%)$ and oleic acid $(4.24 \%)$. While for petroleum ether extract a total of 28 fatty acids were identified the major were: linolenic acid $(42.39 \%)$, linoleic acid $(26.17 \%)$, palmitic acid $(12.89 \%)$, stearic acid $(10.73 \%)$ and methyl erucic $(1.24 \%$.). The oils also, showed good antioxidant activity in relation to control; $28 \pm 0.09$ (DPPH) for $n-H e x a n e$ extract and $26 \pm 0.05$ (DPPH) for petroleum ether extract.

Conclusion: Based on the results obtained flaxseed and flaxseed oil had good potential for human consumption and can be used for other application.

Keywords: Flaxseed; antioxidant; linolenic acid; palmitic acid; oleic acid.

\section{INTRODUCTION}

Flax (Linum usitatissimum) is an annual plant of the Linaceae family. This plant grows to a height up to $60 \mathrm{~cm}$, with slender and very fibrous stems, lanceolate leaves having three veins, up to $4 \mathrm{~cm}$ long and $4 \mathrm{~mm}$ wide, and its bright blue flowers are up to $3 \mathrm{~cm}$ in diameter. The fruit contains a seed known as flaxseed or linseed. Humans have consumed flaxseed since the beginnings of the earliest civilizations. It was used for medical purposes in ancient Egypt and Greece, mainly to relieve abdominal pains and also as energy source [1].The main component of flax seed is oil (36 - 40\%); Flax seed oil's major constituent is LNA (57\%) [1]. Flax seed is an important source of fiber and protein, $30 \%$ and $20 \%$, respectively and is rich in phenolic compounds, known as lignans, responsible for its antioxidant activities [2]. Furthermore, flax seed has been associated with improving the nutritional value by increasing the concentration of omega- 3 fatty acids in different animals and foods, fish, ruminant and dairy goat [2]. Flaxseed has been the focus of increased interest in the field of diet and disease research due to the potential health benefits associated with some of its biologically active components: oil containing approximately $59 \%$ of $\alpha$-linolenic acid $(18: 3 ; \omega 3)$ [3]. The search for novel high-quality but cheap sources of protein and energy has been attaining popularity in developing counties for meeting the challenges of starvation. The attention has been focused on cheap, grains containing relatively high amounts of proteins that can help to enhance the quality of the foods of a large. The flaxseed is one of the grains gaining popularity in this respect [4]. Flaxseed produces a fixed oil known as linseed oil or flaxseed oil [5]. The oil contains unsaturated fatty acids like oleic acid $(12-30 \%)$, linoleic acid $(8-29 \%)$ and linolenic acid $(35-67 \%)$ [5]. The other reason for the rapid increase in the number of omega-3 enhanced foods is the FDA approval of acyanogenic glycosides in flaxseed exists [8]; Qualified health claim on conventional foods containing docosahexaenoic acid (DHA) and eicosapentaenoic acid (EPA) [8]. In addition to the health benefits, flaxseed can be used to improve the nutritive value of bakery products and sensory qualities [6]. Although flaxseed has many health-promoting components, the concern over anti-nutrients such as cadmium and flaxseed oil is one of the few non-edible oils that can be processed into edible-grade products either by genetic improvement or through processing into hydrogenated fats [7]. Recently, flaxseed oil has gained popularity as a nutritional supplement due to greater consumer awareness of the high a-linolenic acid. The increasing demand for flaxseed oil did not only increase the activity level of flaxseed oil extraction but also increased the amounts of the by-products generated (e.g. flaxseed cake/meal) from the extraction process. Commercially flaxseed oil is extracted by pressing the whole flaxseed with or without heating [8]. The beneficial effects are mostly due to flax lipids. Flax oil is the richest plant source of linoleum (omega-6) and linolenic (omega-3) polyunsaturated fatty acids (PUFA), which are essential for humans since they cannot be synthesized in the organism and must be ingested in food [9]. Flaxseeds were also used as medicines in ancient times as cough remedy 
and to relieve the abdominal pain [10]. Oil has been reported to exhibit anti-inflammatory, analgesic, antipyretic and anti-arthritic activity [9]. The seed oil of flax (L. usitatissimum) is notable for its high level of linolenic acid, generally around $45 \%$ to $65 \%$, which gives it a high drying quality, making it useful for industrial purposes. The main objectives of this study were to investigate the proximate composition of flaxseed, physicochemical properties, chemical composition and antioxidant activity of flaxseed oil.

\section{MATERIALS AND METHODS}

\subsection{Samples Collection and Preparation}

Flaxseed (Linum usitatissimum L.) samples were provided by the National Centre for Research, Khartoum - Sudan. They were cleaned from dirt; shade dried, crushed, milled to proper size and then kept in polyethylene bags for further work at room temperature.

\subsection{Proximate Compositions}

The moisture, ash, crude fibre, fat, protein and total carbohydrate (determined by difference) contents of the flax seeds were determined according to official methods described by AOAC [11].

\subsection{Flaxseed Oil Extraction}

The oil was extracted from flaxseed using Soxhlet with $\mathrm{n}$-hexane and petroleum ether (40 $\left.60^{\circ} \mathrm{C}\right) ; 200 \mathrm{~g}$ of prepared seed samples were packed in extraction thimble and inserted into the Soxhlet extractor, the solvents $(500 \mathrm{~mL})$ were separately refluxed for $8 \mathrm{~h}$. At the end of the period, each of the solvents was recovered by rotary evaporator and residual oil was oven dried at $60^{\circ} \mathrm{C}$ for $30 \mathrm{~min}$. The obtained oils were allowed to cold to room temperature before analysis [11]. The yield percentage was calculated using equation (1).

Yield percentage of oil $=\frac{\text { mass of oil }}{\text { mass of sample }} \times 100 \%$

\subsection{Determinations of Physicochemical Properties of Flaxseed Oil}

The density, refractive index, kinematic viscosity and colour were determined using the procedures described by Erwa et al. [12].

\subsubsection{Acid value}

Acid value was determined according to the method of ISO 660:1996. About $10 \mathrm{~g}$ oil sample was accurately weighed in a $250 \mathrm{~mL}$ conical flask; $50 \mathrm{~mL}$ of a mixture solvent (ethanol + diethyl ether) was added to the flask and then about three drops of phenolphthalein indicator solution were added. The mixture was boiled for about five minutes and titrated against standard alkali solution with vigorous shaking during the titration [13].

The acid value, AV, was determined using equation (2)

Acid value $\left(m g \mathrm{KOH} g^{-1}\right)=\frac{(V-b) \times N \times 561}{W}$

Where: $56.1=$ molecular weight of potassium hydroxide $(\mathrm{g} / \mathrm{mol}) ; \mathrm{V}=$ Volume in $\mathrm{mL}$ of standard potassium hydroxide used for sample titration; $b$ = Volume in $\mathrm{mL}$ of standard potassium hydroxide used for blank titration; $N=$ Normality of the potassium hydroxide solution; and $W=$ Weight in $\mathrm{g}$ of the sample.

\subsubsection{Free fatty acid}

According to the definition of FFA\%, it is the mass percentage of oleic acid (mg) in oil (g). The free fatty acid (FFA \%) was calculated from titration results using equation (3).

$F F A \%=\frac{(V-b) \times N \times 28.2}{W}$

Where: $V$ is the volume $(\mathrm{mL})$ of the titre, $b$ is blank titre volume $(\mathrm{mL}), N$ is the normality of potassium hydroxide solution, 28.2 is the molecular weight of oleic acid (282) divided by 10 and $W$ is the weight of the oil used.

\subsubsection{Saponification value}

About $2.0 \mathrm{~g}$ of sample were transferred into a $200 \mathrm{~mL}$ conical flask; $20 \mathrm{~mL}$ of $0.5 \mathrm{~mol} / \mathrm{L}$ alcoholic potassium hydroxide was added. The flask was gently heated and occasionally shaken for 30 minutes and cooled. The unreacted $\mathrm{KOH}$ was then back-titrated with $0.5 \mathrm{~mol} / \mathrm{L} \mathrm{HCl}$. A blank titration was performed [14].

The saponification value (SV) in $\mathrm{mg} / \mathrm{g}$ was calculated using equation (4)

Saponification value $=\frac{(B-V) \times M \times 561}{W}$ 
Where: $B=$ blank titre volume $(\mathrm{mL}) ; V=$ Sample titre volume $(\mathrm{mL}) ; M=$ molarity of the $\mathrm{HCl} ; 56.1=$ the molecular weight of $\mathrm{KOH} ; W=$ weight of sample (g).

\subsubsection{Unsaponifiable matter}

Accurately $5 \mathrm{~g}$ of well oil sample were weighed into a $250 \mathrm{~mL}$ conical flask; $50 \mathrm{~mL}$ of alcoholic potassium hydroxide solution were added. The content was boiled under reflux air condenser for one hour or until the saponification is complete (complete saponification gives a homogeneous and transparent medium). The condenser was washed with about $10 \mathrm{~mL}$ of ethyl alcohol. The saponified mixture was transferred while still warm to a separating funnel. The saponification flask washed first with some ethyl alcohol and then with cold water, using a total of $50 \mathrm{~mL}$ of water to rinse the flask. Cool to $25^{\circ} \mathrm{C}$. A $50 \mathrm{~mL}$ of petroleum ether was added to the flask, shaken vigorously, and allowed the layers to separate. The lower soap layer was transferred into another separating funnel and the extraction was repeated three times using $50 \mathrm{~mL}$ portions of petroleum ether. The combined ether extract was washed three times with $25 \mathrm{~mL}$ portions of aqueous ethyl alcohol followed by washing with $25 \mathrm{~mL}$ portions of distilled water to ensure ether extract is free of alkali (washing are no longer alkaline to phenolphthalein). The solution was transferred to $250 \mathrm{~mL}$ beaker; the separator was rinsed with ether, the rinsing was added to main solution, evaporated to about $5 \mathrm{~mL}$ and transferred quantitatively using several portions [15].

\subsubsection{Peroxide value}

Peroxide value was determined according to ISO 3960: 2007. About $5 \mathrm{~g}$ of the sample were added to $30 \mathrm{~mL}$ of the solvent mixture (acetic acid: chloroform, 2:1 v/v) $5 \mathrm{~mL}$ of saturated potassium iodide were added; the mixture was gently shake and boiled for one minute. The flask left at room temperature in dark, $30 \mathrm{~mL}$ of distilled water were added, and the flask sealed and stirred. Few drops of starch solution were added to the mixture and the latter was titrated with $0.01 \mathrm{~N}$ $\mathrm{Na}_{2} \mathrm{~S}_{2} \mathrm{O}_{3}$ solution. A blank titration was performed [16]. The peroxide value, expressed as mille equivalent of peroxide oxygen per $\mathrm{kg}$ sample $(\mathrm{meq} / \mathrm{kg})$, was calculated using equation (5).

Peroxide value $(\mathrm{meq} / \mathrm{kg})=\frac{(A-B) \times N \times 100}{W}$
Where: $A=$ volume $(\mathrm{mL})$ of $\mathrm{Na}_{2} \mathrm{~S}_{2} \mathrm{O}_{3}$ solution consumed in sample titration; $B=$ volume $(\mathrm{mL})$ of $\mathrm{Na}_{2} \mathrm{~S}_{2} \mathrm{O}_{3}$ solution consumed in blank titration; $N=$ Normality of sodium thiosulphate solution, $w=$ weight of the sample $(\mathrm{g})$.

\subsection{6 lodine value}

lodine value was determined according to ISO 3961:199. About $0.1 \mathrm{~g}$ sample was dissolved in $20 \mathrm{~mL}$ of carbon tetrachloride in a conical flask. About $25 \mathrm{~mL}$ of Hanus solution was added and the flask was sealed. The flask content was shaken for one minute and left in a dark room at $20^{\circ} \mathrm{C}$ for 30 minutes with continuous shaking every 5 minutes. A $10 \mathrm{~mL}$ of $15 \%$ potassium iodide and $100 \mathrm{~mL}$ of distilled water were added, and the flask sealed and shaked for 30 seconds. The liberated iodine was titrated with $0.1 \mathrm{M}$ sodium thiosulphate solution using starch indicator. A blank test was carried out using the same procedure [17].

The lodine value was calculated using equation (6).

Iodine value $(g / 100 g)=\frac{(S-B) \times M \times 12.69}{W}$

Where: $B=$ blank titre volume $(\mathrm{mL}), S=$ sample titre volume $(\mathrm{mL}), M=$ molarity of $\mathrm{Na}_{2} \mathrm{~S}_{2} \mathrm{O}_{3}, W=$ sample weight $(\mathrm{g})$ and $12.69=$ conversion factor from meq. N.

\subsection{GC-MS Analysis}

\subsubsection{Sample preparation}

About $2 \mathrm{~mL}$ of the oil was mixed thoroughly with $7 \mathrm{~mL}$ of alcoholic sodium hydroxide (prepared by dissolving $2 \mathrm{~g}$ in $100 \mathrm{~mL}$ methanol). Also $7 \mathrm{~mL}$ of alcoholic sulfuric acid (prepared by adding 1 $\mathrm{mL}$ of $\mathrm{H}_{2} \mathrm{SO}_{4}$ to $100 \mathrm{~mL}$ methanol) were then added. The mixture was shaken for 5 minutes. The content of the test tube was left to stand overnight. $1 \mathrm{~mL}$ of super saturated sodium chloride was then added and the contents were shaken. $2 \mathrm{~mL}$ of normal hexane were added and the contents were shaken thoroughly for three minutes. The n-hexane layer was taken using disposable syringe. $5 \mu \mathrm{l}$ from the $\mathrm{n}$ hexane extract were diluted with $5 \mathrm{~mL}$ of diethyl ether; then filtered through syringe filter 0.45 $\mu \mathrm{m}$ and dried with' $1 \mathrm{~g}$ of anhydrous sodium sulphate as drying agent; $1 \mu \mathrm{l}$ of the diluted sample was injected in the instrument GC-MS. 


\subsubsection{Method of analysis}

The qualitative and quantitative analysis of the sample was carried out by using 'Simadzu GC/MS model (GC/MS-QP2010-Ultra) coupled with Shimadzu TQ8040 plus mass spectroscopy detector from Japans, equipped with capillary column (Rtx-5 ms - $30 \mathrm{~m} \times 0.25 \mathrm{~mm} \times 0.25$ $\mu \mathrm{m})$. The sample was injected by using split mode, helium as the carrier gas passed with flow rate $1.61 \mathrm{~mL} / \mathrm{min}$, the temperature program was started from $60^{\circ} \mathrm{C}$ with rate $10^{\circ} \mathrm{C} / \mathrm{min}$ to $300^{\circ} \mathrm{C}$ as final temperature degree with 3 min hold time, the injection port temperature was $300^{\circ} \mathrm{C}$, the ion source temperature was $200^{\circ} \mathrm{C}$ and the interface temperature was $250^{\circ} \mathrm{C}$. The sample was analyzed by using scan mode in the range of $\mathrm{m} / \mathrm{z}$ 40 - 500 charges to ratio and the total run time was $27 \mathrm{~min}$. Identification of components was achieved by comparing their retention index and mass fragmentation patents with those available in the library, the National Institute of Standards and Technology (NIST), results were recorded.

\subsection{Antioxidant Activity}

DPPH radical scavenging assay: The DPPH radical scavenging was determined according to the method of Shimada et al. [18] with some modification. In 96-wells plate, the test samples were allowed to react with 2,2-Di(4-tertoctylphenyl)-1-picryl-hydrazyl stable free radical (DPPH) for half an hour at $37^{\circ} \mathrm{C}$. The concentration of DPPH was kept as $(3.0 \mathrm{mM})$. The test samples were dissolved in Dimethyl sulphoxide (DMSO) while DPPH was prepared in ethanol. After incubation, the decrease in absorbance was measured at $517 \mathrm{~nm}$ using a spectrophotometer. Percentage radical scavenging activity by samples was determined in comparison with a DMSO treated control group. All tests analysis was run in triplicate [18].

\subsection{Statistical Treatment of Data}

Statistical analysis of the results was done using MS Excel version (2010). The 95\% confidence level $(\mu)$ for the obtained data of the different parameter values was determined using equation (7) [12].

$\mu=\bar{x} \pm \frac{t s}{\sqrt{n}}$

Where: $\bar{x}$ is the mean; $t$ is Student's $\mathrm{t} ; s$ is the sample standard deviation and $n$ is a number of data.

The data were presented as mean \pm standard deviation (SD). A probability level of less than .05 was chosen statistically significant. For detecting systematic errors, the experimental means of the two data sets of the physicochemical properties are compared using Student's $t$ test, using equation (8).

$t_{\text {calculatd }}=\frac{\left|\bar{x}_{1}-\bar{x}_{2}\right|}{s_{\text {pooled }}} \sqrt{\frac{n_{1} n_{2}}{n_{1}-n_{2}}}$

\section{RESULTS AND DISCUSSION}

\subsection{Proximate Composition of Flaxseed}

The proximate composition of flaxseed was determined using official methods described by $A O A C$ and the results obtained are presented in Table 1. The proximate analysis of flaxseed, as shown in Table 1, revealed that flaxseed is a good source of fats, proteins and fibers, and a poor source of carbohydrates $(5.14 \pm 2.73 \%)$. The crude fat content of flaxseed is relatively higher $(43.17 \pm 0.99 \%)$ than that presented by Priyanka Kajla et al. [2] (37.10\%), Berrin Bozan et al. [20] (33.60\%) and Chetana et al. [23] $(29.61 \%)$ and less than that reported by Rubel et al. [1] (45.20\%); the variation in crude fat content of flaxseed maybe due to environmental conditions and so as for other constituents. The protein content of the flaxseed was found to be $(21.00 \pm 0.74 \%)$ which is in agreement with $22.65 \%$ and $20.30 \%$ obtained by Wahid Herchi et al [21] and Priyanka Kajla et al. [2] respectively. Average fiber content $(20.23 \pm 3.47 \%)$, is very high compared with that reported by Berrin Bozan et al. [20] (1.38\%) and Chetana et al. [23] $(3.08 \%)$. The moisture content of the flaxseed was determined to be $8.50 \pm 0.49 \%$ which is slightly higher than $7.40 \%, 7.1 \%$ and $6.40 \%$ determined by Rubel et al. [1], Sudha et al. [22] and Berrin Bozan et al. [20] respectively. The ash content was $1.96 \%$ which was closed to the result reported by Sargi et al. [3].

\subsection{Extraction of Flaxseed Oil}

The prepared samples of flaxseed were subjected to extraction of oil using petroleum ether and n-hexane in a Soxhlet apparatus for 8 h. The yields obtained were $29.28 \%$ and $21.95 \%$ for petroleum ether and n-hexane respectively. Although these yields are considered high, but it's still less than the very high percentages $49.2 \%$ and $40.3 \%$ obtained by Wanasundara [23] and Rubilar [1] respectively. However it's close to $19.3 \%$ which is reported by Oomah et al. [24] for $\mathrm{n}$-Hexane extract. Another study [21] recorded a percentage of $35.10 \%$. This variation in the extraction percentages can be attributed to 
diversity of climate, soil and differences in species of the plant.

Table 1. Proximate composition of flaxseed

\begin{tabular}{ll}
\hline Constituents & $\begin{array}{l}\text { Percentage } \\
\text { composition }\end{array}$ \\
\hline Moisture (\%) & $8.50 \pm 0.49$ \\
Ash (\%) & $1.96 \pm 0.00$ \\
Crude Protein (\%) & $21.00 \pm 0.74$ \\
Crude Fat (\%) & $43.17 \pm 0.99$ \\
Crude Fiber (\%) & $20.23 \pm 3.47$ \\
Carbohydrate (\%) & $5.14 \pm 2.73$ \\
\hline \multicolumn{2}{l}{ Values are means \pm standard deviations; $n=3, P=$} \\
\end{tabular}

\subsection{Physiochemical Properties of Flax- seed Oil}

The physiochemical properties of extracted flaxseed oil were investigated and the results obtained were shown in Table 2.

The obtained results of physiochemical properties of extracted flaxseed oil, presented in Table 2, showed that there is matching in density $\left(0.92 \pm 0.00 \mathrm{~g} / \mathrm{cm}^{3}\right)$ and refractive index $(1.47 \pm$ 0.00 and $1.48 \pm 0.01$ ) of flaxseed oil extracted by $\mathrm{n}$-hexane and petroleum ether. These values are within the range reported in previous studies $[25,26,27]$.

The saponification number of the oil was relatively high $(185.61 \pm 0.56 \mathrm{mg} \mathrm{KOH} / \mathrm{g}$ for $\mathrm{n}$ hexane extract and $187.83 \pm 2.08 \mathrm{mg} \mathrm{KOH} / \mathrm{g}$ for petroleum ether extract), these values are compared with 190 and $198 \mathrm{mg} \mathrm{KOH} / \mathrm{g}$ obtained by Popa et al. [25] and Herchi et al. [21] respectively. Wherein, a high saponification value increases the opportunities of the oil to being used in soap making.

lodine value, which is considered as one of the parameters used to determine the oil quality, refers to the presence of unsaturated fatty acids in oils, which reflects the susceptibility of oil to oxidation. The obtained results of iodine value was closed to the result obtained by Zhang et al. [26], $195.03 \mathrm{~g} / 100 \mathrm{~g}$, but higher than that obtained by Herchi et al. [21] (160) and Hossein et al. [5] $(126 \pm 0.4)$

Peroxide value, a widely used test for rancidity in oils, gives an idea about the early stages of oil oxidation. The results showed that the peroxide values of flaxseed oil $(2.69 \pm 0.55$ to $4.67 \pm 1.00$ meq $\mathrm{O}_{2} / \mathrm{kg}$ ) are less than the allowed value for raw vegetable oils. Some authors have reported peroxide values of even less than our finds $[21,25,26]$. Despite the expectations indicate that the flaxseed oil is susceptible to fast oxidation, and hence to rancidity, due to presence of high content of unsaturated fatty acids, but this did not observed may be due to presence of high antioxidant content.

The acid value is a measure of the free fatty acids content in oil. The acid values of the flaxseed oil $(0.75 \pm 0.20$ to $0.76 \pm 0.20 \mathrm{mg} \mathrm{KOH}$ $\mathrm{g}^{-1}$ Oil) were less than the Codex standard value (4.0 $\mathrm{mg} \mathrm{KOH} \mathrm{g}^{-1}$ Oil) for virgin vegetable oils [19]. This result was similar to the results obtained in previous studies $[25,26]$.

In order to detect the influence of extraction solvent on the physicochemical properties of flaxseed oil, to decide whether a change of the solvent affects the results, the statistical student's t-test was performed to decide whether the difference between the two means is significant, i.e. to test the null hypothesis, $\mathrm{H}_{0}: \mu_{1}$ $\mu_{2}=0$, therefore the experimental result, $\left(\bar{x}_{1}-\right.$ $\bar{x}_{2}$ ) was tested to see whether it differs significantly from zero or not. The data showed that the statistic $F_{\text {calculated }}$ values $\left(F_{\text {calculated }}=\frac{s_{1}^{2}}{s_{2}^{2}}\right)$ for five properties are much less than the critical value $\mathrm{F}_{2,2}=19.0(P=.05)$, so the null hypothesis of equal variances is retained: there is no significant difference between the standard

Table 2. Physiochemical properties of the flaxseed oils

\begin{tabular}{lll}
\hline Property & n-Hexane extract & P. ether extract \\
\hline Acid value $(\mathrm{mg} \mathrm{KOH} / \mathrm{g}$ oil) & $0.76 \pm 0.10$ & $0.75 \pm 0.20$ \\
Saponification value $(\mathrm{mg} \mathrm{KOH} / \mathrm{g}$ oil) & $185.61 \pm 0.56$ & $187.83 \pm 2.08$ \\
Unsaponifiable matter $(\mathrm{mg} \mathrm{KOH} / \mathrm{g}$ oil) & $5.57 \pm 0.64$ & $2.83 \pm 0.23$ \\
Peroxide value $\left(\mathrm{meq} \mathrm{O}_{2} / \mathrm{kg}\right)$ & $4.67 \pm 1.00$ & $2.69 \pm 0.55$ \\
lodine value $(\mathrm{g} / 100 \mathrm{~g})$ & $97.24 \pm 0.86$ & $97.44 \pm 2.93$ \\
Density $\left(\mathrm{g} / \mathrm{cm}^{3}\right)$ & $0.92 \pm 0.00$ & $0.92 \pm 0.00$ \\
Kinematic viscosity $(\mathrm{cSt})$ & $70.36 \pm 0.13$ & $67.35 \pm 0.35$ \\
Refractive index & $1.47 \pm 0.00$ & $1.48 \pm 0.01$ \\
Color & $35.30 \pm 0.10$ & $34.60 \pm 0.14$ \\
\hline
\end{tabular}


deviations of the two data sets at the $5 \%$ level. The observed values of $|t|$, Table 3 , are less than the critical value, $t_{4}=2.78(P=.05)$, so the null hypothesis is retained: there is no evidence that the change of solvent in this work affects the physicochemical properties of flaxseed oil suggesting that the two set of results agree within the experimental error.

Table 3. T tests for chemical properties of flaxseed oil

\begin{tabular}{llc}
\hline Property & $\mathbf{t}_{\text {calculated }}$ & $\mathbf{T}_{\text {table }}$ \\
\hline Acid value & 1.56 & \\
Saponification value & 1.89 & \\
Un Saponification value & 2.51 & 2.78 \\
Peroxide value & 2.48 & \\
lodine value & 0.11 & \\
\hline \multicolumn{2}{c}{ Confidence interval $95 \%, n_{1}=3$ and $n_{2}=3$}
\end{tabular}

\subsection{Fatty Acid Composition}

The extracted oils of flaxseed with $\mathrm{n}$-Hexane and petroleum ether were investigated also for the fatty acids content using GC-MS instrument and the results were presented in Table 4 which showed the predominant fatty acids in n-Hexane and petroleum ether extracts. The GC-MS analysis of flaxseed oil extracted using $n$-Hexane revealed the presence of 27 fatty acids; the major identified fatty acids were linoleic acid $(46.53 \%)$, palmitic acid $(18.04 \%)$, stearic acid $(12.23 \%)$, linolenic acid $(11.63 \%)$ and oleic acid $(4.24 \%)$. To some extent this arrangement is compatible with that reported by Berrin Bozan et al. [20], wherein; linolenic acid (58.31\%) was more than our result, while linoleic acid content $(13.96 \%)$ was less than our result, but oleic acid percentage $(15.07 \%)$ was higher than that obtained in this research. In addition the GC-MS analysis of flaxseed oil extracted using petroleum ether revealed the presence of 28 fatty acids; the major identified fatty acids were linolenic acid $(42.39 \%)$, linoleic acid $(26.17 \%)$, palmitic acid $(12.89 \%)$, stearic acid $(10.73 \%)$ and erucic acid $(1.24 \%)$. These results were compared to the results obtained by Popa et al. [25], which were linolenic acid (53.21\%), linoleic acid (17.25\%), stearic acid (4.43\%) and palmitic acid (6.58\%). Rubilar et al [1], also their results were linolenic acid $(49.3 \%)$ was higher and linoleic acid $(14.7 \%)$ was lower than our obtained results. The results obtained by Herchi et al. [21] showed that the palmitic acid content $(6.62 \%)$, stearic acid $(5.81 \%)$ and linoleic acid $(15.77 \%)$ were lower than our results, but linolenic acid $(42.53 \%)$ was almost the same as our result. The variation in the content of fatty acids is may be due to environmental factors as well as the difference in solvents used.

\subsection{Antioxidant Activity}

Naturally occurring antioxidants in food products attract more attention due to their clear role as anti-carcinogenic agents and as inhibitors of biologically harmful oxidation processes occurring in human's body. The oxidative stability is an important factor for potential utilizations of oils in food and other commercial products. In this work the extracted oils of flaxseed with nHexane and petroleum ether were subjected to antioxidant activity test and the results shown in Table 5. Antioxidant activity of flaxseed oil extracted by petroleum ether was $26 \pm 0.05 \%$ $(\mathrm{DPPH})$ and for $\mathrm{n}$-Hexane extract was $28 \pm$ $0.09 \%$ (DPPH). Siger et al. [28] and

Table 4. Major fatty acids content of flaxseed oil

\begin{tabular}{llllll}
\hline $\begin{array}{l}\text { Type of fatty } \\
\text { acid }\end{array}$ & Lipid numbers & Common name & Formula & \multicolumn{2}{c}{ Area \% } \\
\cline { 5 - 6 } Saturated & & & & n-Hexane & P. ether \\
\multirow{2}{*}{ Monounsaturated } & $\mathrm{C} 16: 0$ & Palmitic acid & $\mathrm{C}_{16} \mathrm{H}_{32} \mathrm{O}_{2}$ & 18.04 & 12.89 \\
& $\mathrm{C} 18: 1 \mathrm{n}-9$ & Stearic acid & $\mathrm{C}_{18} \mathrm{H}_{36} \mathrm{O}_{2}$ & 12.23 & 10.73 \\
Polyunsaturated & Oleic acid & $\mathrm{C}_{18} \mathrm{H}_{34} \mathrm{O}_{2}$ & 4.24 & - \\
& $\mathrm{C} 18: 1 \mathrm{n}-13$ & Erucic acid & $\mathrm{C}_{22} \mathrm{H}_{42} \mathrm{O}_{2}$ & - & 1.24 \\
& $\mathrm{C} 18: 3 \mathrm{n}-9,12,15$ & Linoleic acid & $\mathrm{C}_{18} \mathrm{H}_{32} \mathrm{O}_{2}$ & 46.53 & 26.17 \\
\hline
\end{tabular}

Table 5. Antioxidant activity of flaxseed oils (RST \pm SD \% (DPPH))

\begin{tabular}{llll}
\hline NO. & Sample code & n-Hexane & P. ether \\
\hline 1 & Flaxseed oil & $28 \pm 0.09$ & $26 \pm 0.05$ \\
Standard & Propyl gallate & $92 \pm 0.01$ & $91 \pm 0.01$ \\
\hline \multicolumn{4}{c}{} \\
\hline
\end{tabular}


Sargi et al. [3], their antioxidant activity results $(19.3 \pm 2.1)$ and $(1.56 \pm 0.01)$ respectively; were less than our obtained results. However Anwar et al. [29] antioxidant activity result (42 \pm 0.06$)$ was higher than our result.

\section{CONCLUSION}

In the last two decades, flaxseed has been the focus of increased interest in the field of diet and disease research due to the potential health benefits associated with some of its biologically active components. The objectives of this research were to investigate the proximate composition of flaxseed; in addition to investigate the physiochemical properties and antioxidant activity of flaxseed oil. The prepared sample of flaxseeds was tested for proximate composition and then extracted with two different solvents. The extracted oils were then subjected to physiochemical analysis tests, GCMS analysis and antioxidant activity test. The oil yield of flaxseed with $n$-Hexane was $21.95 \%$ and petroleum ether was $28.29 \%$. However, the solvent type has no significant effect on physicochemical characteristics of the extracted oils. The physicochemical characteristics indicate good stability of the oil. The GC-MS analysis results of flaxseed oil extracted with nHexane showed 27 components, the predominant fatty acids were linoleic acid, palmitic acid, stearic acid, linolenic acid and oleic acid. while for petroleum ether extract a total of 22 components were identified, the predominant compositions were linolenic acid, linoleic acid, palmitic acid, stearic acid and erucic acid. Furthermore the antioxidant result of flaxseed oil extracted showed that flaxseed oil exhibit very good oxidative stability.

\section{ACKNOWLEDGEMENTS}

Authors are grateful to the lab staff of Department of Applied and Industrial Chemistry, International University of Africa for providing space and resources to carry out this work.

\section{COMPETING INTERESTS}

Authors have declared that no competing interests exist.

\section{REFERENCES}

1. Rubilar M, Gutiérrez C, Verdugo M, Shene C, Sineiro J. Flaxseed as a source of functional ingredients. J. Soil. Sci. Plant Nutr. 2010;10(3):373-7.

Available: http://dx.doi.org/10.4067/S071895162010000100010

2. Kajla P, Sharma A, Sood DR. Flaxseed a potential functional food source. J. Food Sci. technol. 2015;52(4):1857-71.

Available: https://doi.org/10.1007/s13197014-1293-y

3. Sargi SC, Silva BC, Santos HM, Montanher PF, Boeing JS, Júnior $S$, Oliveira O, Souza NE, Visentainer JV. Antioxidant capacity and chemical composition in seeds rich in omega-3: chia, flax, and perilla. Food Sci. Technol. 2013;33(3):541-8.

Available: http://dx.doi.org/10.1590/S010120612013005000057

4. Kitts DD, Yuan YV, Wijewickreme AN, Thompson LU. Antioxidant activity of the flaxseed lignan secoisolariciresinol diglycoside and its mammalian lignan metabolites enterodiol and enterolactone. Mol. Cell. Biochem. 1999;202(1-2):91100.

Available:https://doi.org/10.1023/A:100702 2329660

5. Hussain S, Anjum FM, Butt MS, Sheikh MA. Chemical composition and functional properties of flaxseed (Linum usitatissimum) flour. Sarhad J. Agric. 2008;24(4):649-53.

6. Bekhit AE, Shavandi A, Jodjaja T, Birch J, Teh S, Ahmed IA, Al-Juhaimi FY, Saeedi P, Bekhit AA. Flaxseed: Composition, detoxification, utilization and opportunities. Biocatal. Agric. Biotechnol. 2018; 13:129-52.

Available:https://doi.org/10.1016/j.bcab.20 17.11.017

7. Kaithwas G, Mukerjee A, Kumar P, Majumdar DK. Linum usitatissimum (linseed/flaxseed) fixed oil: Antimicrobial activity and efficacy in bovine mastitis. Inflammopharmacology. 2011;19(1):4552.

Available:https://doi.org/10.1007/s10787010-0047-3

8. Vadukapuram $\mathrm{N}$, Hall $\mathrm{C}$, Tulbek $\mathrm{M}$, Niehaus M. Physicochemical properties of flaxseed fortified extruded bean snack. Int. J. Food Sci; 2014.

Available:http://dx.doi.org/10.1155/2014/4 78018

9. El-Beltagi HS, Salama ZA, El-Hariri DM. Evaluation of fatty acids profile and the content of some secondary metabolites in 
seeds of different flax cultivars (Linum usitatissimum L.). Gen. Appl. Plant Physiol. 2007;33(3-4):187-202.

10. Goyal A, Sharma V, Upadhyay N, Gill S Sihag M. Flax and flaxseed oil: An ancient medicine \& modern functional food. J Food Sci Technol. 2014;51(9):1633-53.

11. AOAC. Determination of crude oil. Official methods of analysis. 17th ed. Washington: Association of Official Analytical Chemists; 2000.

12. AOAC. Determination of Crude Oil. Official Methods of Analysis 17th Edition, Association of Official Agric Chem. Washington; 2000.

13. Erwa IY, Ali AM, Khalid EA, Omer AB, Ishag OA. Proximate composition, mineral elements content and physicochemical characteristics of Adansonia digitata L seed Oil. Int J Pharma Bio Sci. 2019; 10(4):119-26.

Available:http://dx.doi.org/10.22376/ijpbs.2 019.10.4.p119-126

14. ISO I. 660: 2009(E) Animal and Vegetable Fats and Oils-Determination of acid value and acidity. ISO: Geneva, Switzerland; 2009.

Available:https://www.sis.se/api/document /preview/911251/

15. ISO 3657:2013(E). Animal and vegetable fats and oils-Determination of saponification value. International Organisation for Standardisation; 2013.

Available:https://www.sis.se/api/document /preview/916338/

16. ISO 1067:1974 Analysis of soaps Determination of unsaponifiable, unsaponified and unsaponified saponifiable matter; 1974.

Available:https://www.iso.org/standard/55 60.htmL

17. ISO 3960: Animal IS. Vegetable fats and oils-determination of peroxide value. International Organization for Standardization. Switzerland; 2007.

Available:https://www.iso.org/standard/39 158.htmL

18. ISO 3961. Animal and vegetable fats and oils: determination of iodine value. International Organization for Standardization. Switzerland; 1996.

Available:Https://Www.Iso.Org/Standard/9 620. HtmL

19. Bozan B, Temelli F. Chemical composition and oxidative stability of flax, safflower and poppy seed and seed oils. Bioresource Technol. 2008;99(14):6354-9.
Available:https://doi.org/10.1016/j.biortech. 2007.12.009

20. Wanasundara PK, Amarowicz R, Kara MT, Shahidi F. Removal of cyanogenic glycosides of flaxseed meal. Food Chem. 1993;48(3):263-6.

Available:https://doi.org/10.1016/0308-

8146(93)90138-6

21. Herchi W, Al Hujaili AD, Sakouhi F, Sebei $\mathrm{K}$, Trabelsi H, Kallel H, Boukhchina S. Flaxseed hull: chemical composition and antioxidant activity during development. J Oleo Sci. 2014; ess14006.

Available:https://doi.org/10.5650/jos.ess14 006

22. Sudha ML, Begum K, Ramasarma PR. Nutritional characteristics of linseed/ flaxseed (Linum usitatissimum) and its application in muffin making. J Texture stud. 2010;41(4):563-78.

Available:https://doi.org/10.1111/j.17454603.2010.00242.x

23. Oomah BD, Sitter L. Characteristics of flaxseed hull oil. Food Chem. 2009; 114(2):623-8.

Available:https://doi.org/10.1016/j.foodche m.2008.09.096

24. Popa VM, Gruia A, Raba DN, Dumbrava D, Moldovan C, Bordean D, Mateescu C. Fatty acids composition and oil characteristics of linseed (Linum Usitatissimum L.) from Romania. J. Agroaliment. Processes Technol. 2012; 18(2):136-40.

25. Zhang ZS, Wang LJ, Li D, Li SJ, Özkan N. Characteristics of flaxseed oil from two different flax plants. Int. J. Food Prop. 2011;14(6):1286-96.

Available:https://doi.org/10.1080/1094291 1003650296

26. Choo WS, Birch J, Dufour JP. Physicochemical and quality characteristics of cold-pressed flaxseed oils. J. Food Compos. Anal. 2007;20(3-4):20211.

Available:https://doi.org/10.1016/j.jfca.200 6.12 .002

27. Shimada K, Fujikawa K, Yahara K, Nakamura T. Antioxidative properties of xanthan on the autoxidation of soybean oil in cyclodextrin emulsion. J. Agr. Food Chem. 1992;40(6):945-8.

Available:https://pubs.acs.org/doi/pdf/10.1 021/jf00018a005

28. Siger A, Nogala-Kalucka MA, LampartSzczapa EL. The content and antioxidant activity of phenolic compounds in 
cold-pressed plant oils. J. Food Lipids. 2008;15(2):137-49.

Available:https://doi.org/10.1111/j.17454522.2007.00107.x

29. Anwar F, Przybylski R. Effect of solvents extraction on total phenolics and antioxidant activity of extracts from flaxseed (Linum usitatissimum L.). Acta Sci. Pol., Technol. Aliment. 2012;11(3): 293-302.

Available:https://www.food.actapol.net/pub 19_3_2012.pdf

(c) 2019 Ishag et al.; This is an Open Access article distributed under the terms of the Creative Commons Attribution License (http://creativecommons.org/licenses/by/4.0), which permits unrestricted use, distribution, and reproduction in any medium, provided the original work is properly cited.

Peer-review history:

The peer review history for this paper can be accessed here: http://www.sdiarticle4.com/review-history/53964 